\title{
Rancang Bangun Aplikasi Monitoring Penggunaan Air PDAM Berbasis Mikrokontroler Arduino Uno
}

\author{
Risna \\ Teknik informatika STMIK Atma Luhur \\ Jl.Jend Sudirman Selindung Lama Pangkalpinang \\ Kepulauan Bangka Belitung \\ risna45@gmail.com
}

\begin{abstract}
Abstrak- Tujuan dari penulisan skripsi adalah menghasilkan karya nyata dalam memberikan kenyamanan atau kemudahan dalam monitoring penggunaan debit air pada masyarakat yang menggunakan air PDAM. Hasil yang dicapai adalah meningkatkan aspek kenyamanan dan kemudahan yang umumnya digunakan pada masyarakat awam dalam monitoring penggunaan debit air setiap bulannya, dimana yang sebelumnya menggunakan meteran yang tidak semua orang bisa membacanya, dan rangkaian ini dapat bekerja dengan water flow sensor pada mikrokontroler arduino uno. Sistem kerja sensor ini adalah dengan memanfaatkan fenomena efek hall. Efek hall ini didasarkan pada efek medan magnetik terhadap partikel bermuatan yang bergerak sehingga didapatkan nilai frekuensi. Frekuensi kemudian dikalkulasikan menjadi kecepatan laju air dan volume total. Hasil pengukuran kemudian ditampilkan pada LCD 20x4 karakter berupa laju air dan volume total.
\end{abstract}

Kata Kunci- sensor aliran air G1/2, mikrokontroler arduino uno, $L C D$

\section{PENDAHULUAN}

Air merupakan sumber kehidupan yang sangat diperlukan oleh makhluk hidup, dengan demikian, semakin bertambahnya penduduk maka semakin meningkat pula kebutuhan air yang harus dipenuhi, tidak ada manusia yang tidak membutuhkan air seperti untuk kebutuhan sehari-hari, sarana transportasi dan sebagai sumber energi untuk PLTA (Pembangkit Listrik Tenaga Air).

Meteran air sangat umum dijumpai pada setiap rumah pelanggannya, baik di lingkungan perumahan, perkantoran maupun industri yang bertindak sebagai penghitung besar pemakaian air yang dipakai pelanggan setiap bulannya. Pada umumnya, meteran air dan dipasang di tiap rumah yang berlangganan kepada PDAM (Perusahaan Daerah Air Minum) sebagai penyedia air yang memenuhi kebutuhan air pendudukLatar Belakang Penelitian

\author{
Harrizki Arie Pradana \\ Teknik informatika STMIK Atma Luhur \\ Jl.Jend Sudirman Selindung Lama Pangkalpinang \\ Kepulauan Bangka Belitung \\ harrizkiariep@atmaluhur.ac.id
}

Dalam penyaluran air oleh pihak PDAM, dibutuhkan proses pengecekan atau monitoring jumlah penggunaan air yang disalurkan ke masing-masing pelanggan setiap bulan. Selama ini, pelaksanaan monitoring pemakaian air masih manual, dengan cara mengirimkan petugas secara periodik untuk mendatangi setiap lokasi alat ukur secara langsung. Sistem monitoring tersebut sering kali menimbulkan terjadinya banyak kendala dan kesalahan, sebab sistem tersebut ini kurang efektif dan efisien serta membutuhkan banyak tenaga dan menghabiskan banyak waktu. Selain itu dengan alat yang masih bersifat analog sering terjadi kecurangan yang dilakukan oleh pelanggan yang tak bertanggung jawab dalam jumlah pemakaian volume air yang digunakan.

\section{Metode PNEELITIAN}

Metode merupakan suatu cara untuk memahami alur-alur yang ditempuh dalam penelitian dan didasarkan pada tujuan yang hendak dicapai pada suatu penelitian. Berikut ini metode penelitian yang penulis gunakan untuk mendapatkan data-data yang diperlukan.

\section{A. Studi Literatur}

Pada tahap ini dilakukan penelusuran terhadap berbagai macam literatur seperti buku, referensi-referensi baik melalui perpustakaan maupun internet dan lain sebagainya yang terkait dengan judul penelitian ini.

\section{B. Analisis Sistem}

Analisis sistem dilakukan untuk memberikan arahan dan menentukan tahap proses pengerjaan selanjutnya dalam hal penentuan kebijakan. Analisis sistem dilakukan dengan tahap sebagai berikut:

\section{1) Analisis masalah}

Pada tahap ini dilakukan untuk mengetahuai masalah yang sedang terjadi pada sistem lama atau sistem yang sedang berjalan. 


\section{2) Analisis kebutuhan}

Pada tahap ini dilakukan untuk mengetahuai kebutuhan perangkat keras dan perangkat lunak yang digunakan.

\section{3) Analisis sistem berjalan}

Pada tahap ini dilakukan untuk mengetahui sistem atau proses yang sedang berjalan sekarang, digambarkan dalam activity diagram.

\section{Perancangan Sistem}

Perancangan sistem adalah merancang sistem secara rinci berdasarkan hasil analisis sistem yang ada, sehingga menghasilkan model baru yang diusulkan, perancangan sistem ini menggunakan deployment diagram dan komponen diagram.

\section{Implementasi}

Pada tahap ini adalah proses memaparkan hasil hasil dari instalasi perangkat keras, langkah-langkah instalasi perangkat lunak, dan pengujian. Kemudian hasil dari uji coba tersebut dievaluasi. Apabila terdapat kesalahan atau kekurangan tersebut, maka dapat dilakukan perbaikan yang diperlukan.

\section{PEMBAHASAN}

\section{A. Analisis Sistem}

Analisis sistem adalah metode untuk menentukan kelemahan-kelemahan sistem guna memperoleh gambaran terhadap sistem yang akan dikembangkan sehingga dapat diusulkan perbaikannya. Tahapan dalam menganalisa sistem diawali dengan mempelajari bagaimana mengidentifikasi.

\section{B. Analisa Masalah}

Meteran yang di gunakan oleh pihak PDAM masih manual, sehingga sulitnya konsumen untuk membaca meteran tersebut, monitoring yang di lakukan oleh pihak PDAM masih harus mendatangi setiap lokasi alat ukur secara langsung. Maka hal tersebut penulis merancang sebuah sistem monitoring penggunaan air PDAM berbasis mikrokontroler arduino uno yang dapat memberi kemudahan kepada setiap konsumen untuk menghitung atau monitoring pemakaian air PDAM setiap bulannya

\section{Analisis SIstem Berjalan}

Analisis sistem berjalan yang dilakukan dalam rancangan proyek ini terdiri dari:

- Analisis sistem berjalan, merupakan proses kerja sistem yang terjadi saat ini atau yang sedang berlangsung sebelum dikembangkannya proyek. Dalam tahap analisis sistem berjalan digambarkan dalam bentuk activity diagram. Analisis sistem berjalan cara kerja sistem lama akan dijelaskan pada activity diagram lihat 1 .

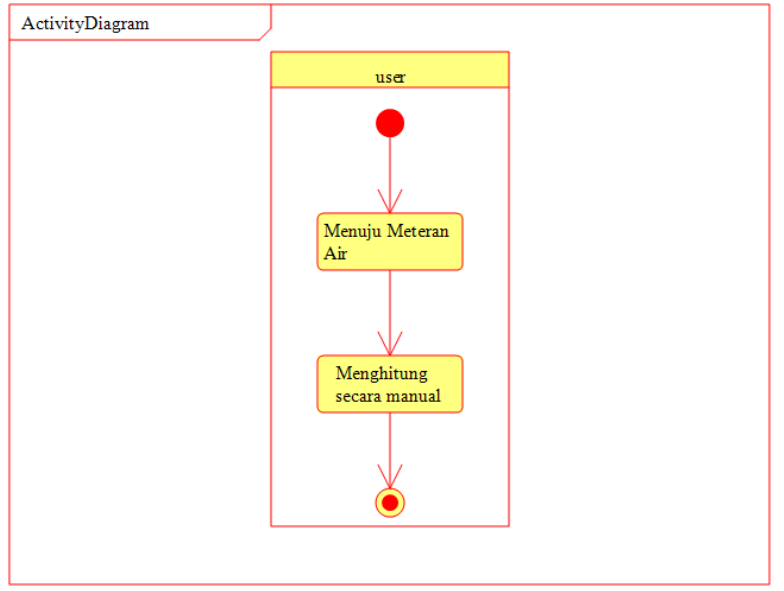

Gambar 1. Activity Diagram Aliran Kerja Sistem Berjalan

- Analisis sistem usulan, kebutuhan sistem yang digunakan untuk membangun rancang bangun monitoring penggunaan air PDAM berbasis mikrokontroler arduino uno sebagai pemroses utama, mikrokontroler arduino uno sebagai pemroses penghitungan air dan ditampilkan pada LCD. Dalam pembuatan program (editing) menggunakan software arduino IDE yang menggunakan pemrograman bahasa C. Analisis sistem berjalan cara kerja sistem baru akan dijelaskan pada activity diagram lihat Gambar 2.

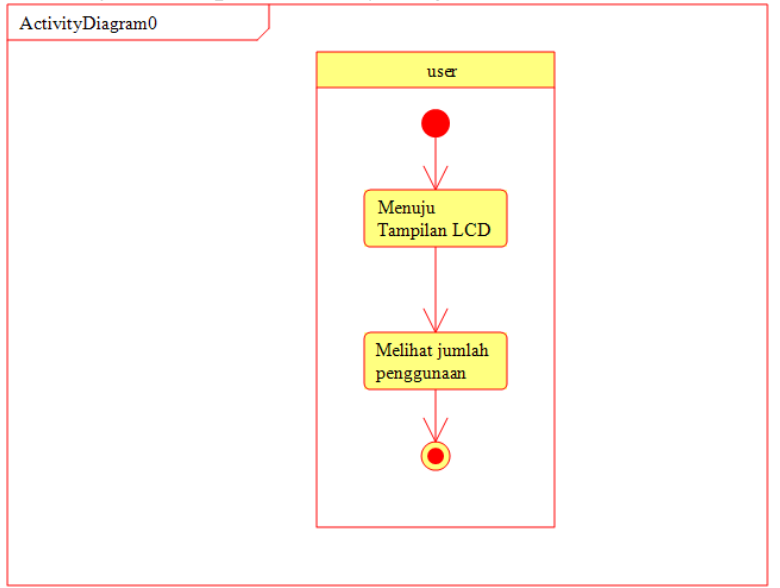

Gambar 2. Activity Diagram aliran kerja sistem baru

\section{Perancangan}

Cara kerja dari rancang bangun monitoring penggunaan air PDAM berbasis mikrokontroler arduino uno adalah ketika water flow sensor mendapat tekanan berupa air atau angin maka water flow sensor akan berputar, putaran water flow ini mendapat sebuah file atau nilai yang dimasukkan kedalam arduino dan arduino ini akan memproses setelah di proses oleh arduino, RTC disini menghasilkan tanggal yang di trasfer ke arduino kemudian semua hasil nya akan ditampilkan pada LCD.

Berdasarkan penjelasan di atas pada tahap ini akan digambarkan terlebih dahulu menggunakan deployment 
diagram. Hal ini akan sangat membantu dalam mengetahui gambaran rancangan hardware. Selain itu deployment diagram juga akan membantu untuk lebih memahami perancangan sistem yang akan dilakukan.adapun untuk melihat deployment diagram.

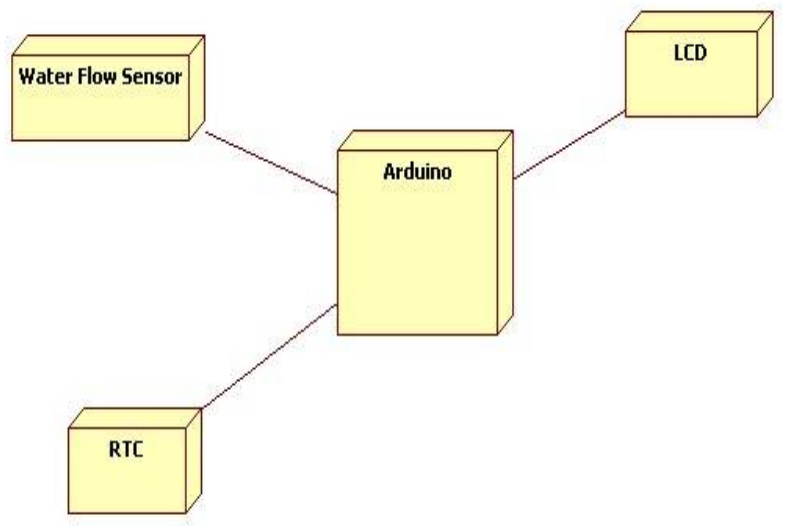

Gambar 3. Deployment Diagram

Dilihat dari deployment diagram pada Gambar 3 dapat diketahui bahwa semua perangkat keras (hardware) saling berhubungan semua dalam rancang bangun aplikasi monitoring penggunaan air PDAM berbasis mikrokontroler ini.

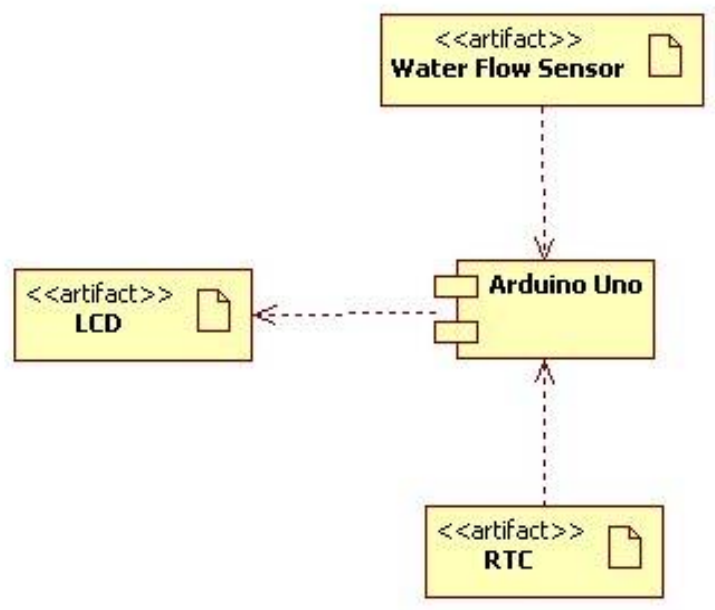

Gambar 4. Komponen Diagram Monitoring Air

Dilihat dari Gambar 4 water flow sensor bertugas sebagai inputan, dimana water flow sensor akan menginput hasil perhitungan ke arduino, disini water flow sensor mengirimkan sebuah nilai hasil perhitungan air ke arduino kemudian RTC ini menghasilkan tanggal yang di transfer ke arduino dan hasilnya akan dilihat pada LCD.

Perancangan proses cara kerja water flow sensor disajikan dalam bentuk flowchart pada Gambar 5 .

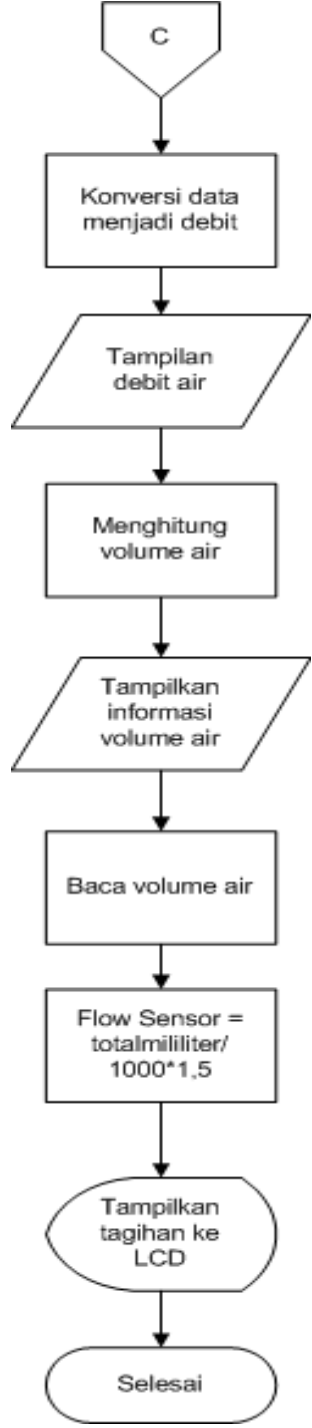

Gambar 5. Flowchart water flow sensor

Tabel 1. Algoritma Cara Kerja Water Flow Sensor

1. If konversi data menjadi informasi debit
2. Then
3. If tampilkan debit air
4. Then
5. If menghitung volume air
6. Then
7. If informasi volume air
8. Then
9. Baca volume air
10.Then
11. Flow sensor = totalmililiter/1000*1,5
12.Else
13.Tampilkan tagihan ke $1 C D$
14.Selesai


Perancangan cara kerja alat secara keseluruhan pada rancang bangun monitoring penggunaan air PDAM berbasis mikrokontroler arduino uno disajikan dalam bentuk flowchart pada Gambar 6.

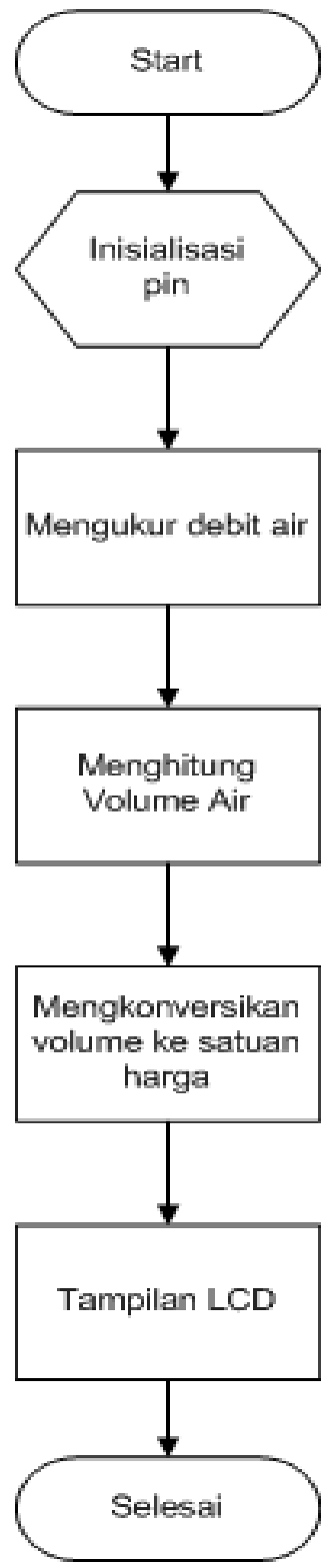

Gambar 7. Flowchart Cara Kerja Keseluruhan

Tabel 2. Algoritma Cara Kerja Alat Keseluruhan
1. If inisialisasi pin
2. Then
3. Mengukur debit air
4. Menghitung volume air
5. Mengkonversikan volume kesatuan harga
6. Else
7. Tampilkan LCD
8. Selesai

\section{E. Implementasi}

Implementasi merupakan kegiatan akhir dari proses penerapan sistem baru, dimana tahap ini merupakan tahap meletakkan sistem supaya siap untuk dioprasikan dan dapat di pandang sebagai usaha untuk mewujudkan sistem yang telah dirancang.

1) Instalasi Perangkat Keras

Instalasi perangkat keras merupakan suatu proses instalasi alat atau perakitan alat yang digunakan dalam rancang bangun aplikasi monitoring penggunaan air PDAM berbasis mikrokontroler arduino uno.

\section{a) Rangkaian $L C D$}

Pada rancangan ini, LCD merupakan keluaran dari rancang bangun aplikasi monitoring penggunaan air PDAM berbasis mikrokontroler arduino uno, dimana pada LCD terdapat 4 pin yaitu GND yang dihubungkan ke negatif breadboard, VCC yang dihubungkan ke positif breadboard, SDA yang dihubungkan ke pin A4 arduino, dan SCL yang dihubungkan ke pin A5 arduino uno, adapun rancangan dari LCD itu sendiri bisa anda lihat Gambar 8

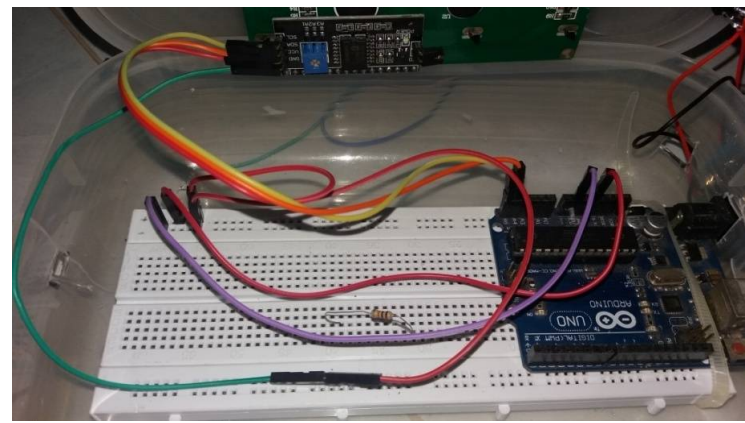

Gambar 8. Rangkaian LCD

\section{b) Rangkaian RTC}

RTC merupakan peralatan yang meyimpan data-data detik, menit, jam, tanggal dan bulan dalam seminggu, dan tahun, pada RTC terdapat 5 pin yaitu VCC yang dihubungkan ke positif breadboard, GND yang dihubungkan ke negatif breadboard, CLK yang dihubungkan ke pin nomor 6 pada arduino, DAT dihubungkan ke pin nomor 7 pada arduino, dan RST yang dihubungkan ke pin nomor 8 arduino.

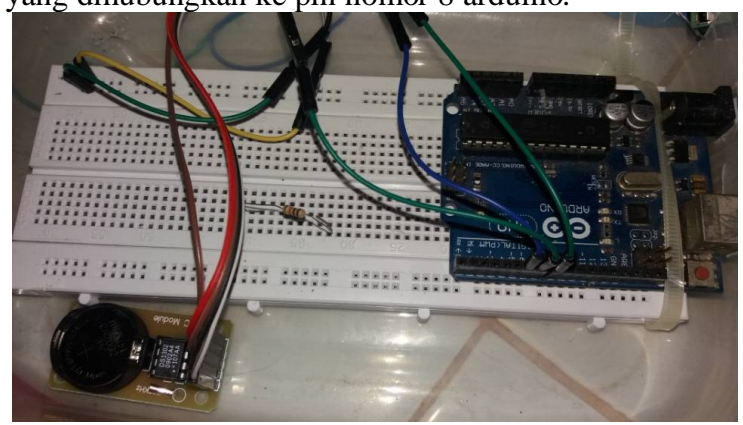

Gambar 9. Rangkaian RTC 
c) Rangkaian Water Flow Sensor

Water Flow Sensor merupakan sensor aliran air yang terdiri dari 3 kabel, dimana kabel-kabel tersebut berwarna merah yang dihubungkan ke positif breadboard, kabel warna kuning dihubungkan ke pin nomor 2 pada arduino, dan kabel warna hitam dihubungkan ke negatif breadboard.

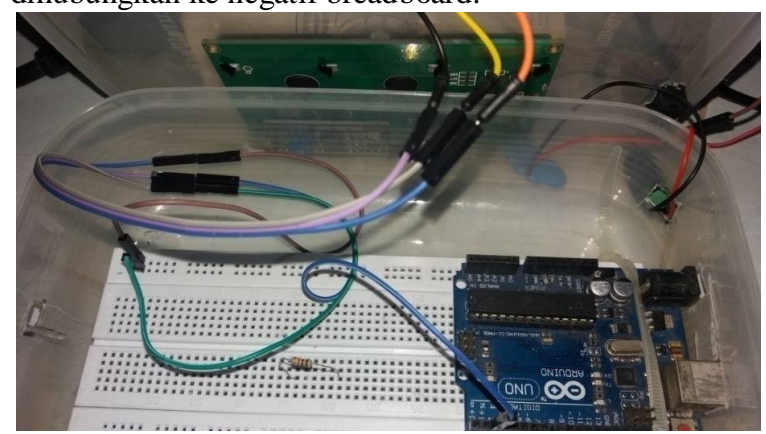

Gambar 10. Rangkaian Water Flow Sensor

\section{d) Rangkaian Keseluruhan}

Pada bagian ini merupakan hasil dari rangkaian alat secara keseluruhan, dimana sudah menjadi suatu prototipe alat yang siap untuk diujicoba.

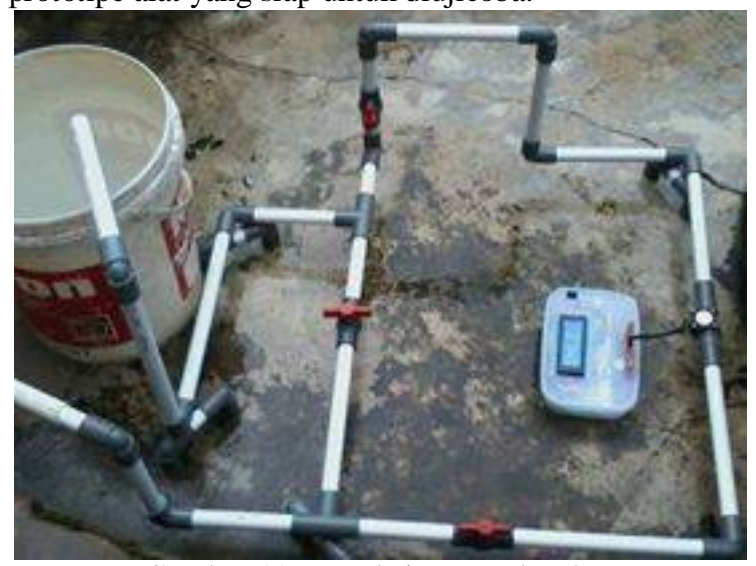

Gambar 11. Rangkaian Keseluruhan

\section{2) Blackbox Testing}

Tahapan pengujian adalah tahapan akhir saat semua proses dilalui dengan tujuan untuk mengetahui apakah alat yang dirancang telah sesuai dengan hasil yang diharapkan.

Pengujian ini menggunakan metode BlackBox Testing, dimana pengujian ini memfokuskan pada kebutuhan fungsional perangkat dengan tujuan berusaha menemukan kesalahan, kesalahan yang dimaksud adalah kesalahan fungsi, kesalahan intreface, kesalahan struktur data, ataupun kesalahan kinerja.

\section{a) Pengujian Arduino Uno}

Pengujian sis tem Arduino Uno ini dilakukan untuk untuk mengetahui keluaran yang dihasilkan apakah sesuai dengan program. Pengujian ini dilakukan dengan cara memprogram sistem Arduino Uno dan diukur secara berulang-ulang. Pengujian berhasil jika keluaran sama dengan program yang telah di input.

Tabel 3. Hasil Pengujian Arduino Uno

\begin{tabular}{|l|l|l|c|}
\hline Status & $\begin{array}{l}\text { Yang } \\
\text { diharapkan }\end{array}$ & Pengamatan & Kesimpulan \\
\hline Aktif & $\begin{array}{l}\text { Program yang } \\
\text { diinput sama } \\
\text { dengan output. }\end{array}$ & Pada LCD & Valid \\
\hline
\end{tabular}

Pada tabel pengujian arduino uno diatas dapat dijelaskan, pada saat status aktif yang diharapkan program yang diinput sama dengan output hasil pengamatan bisa anda lihat pada tampilan LCD.

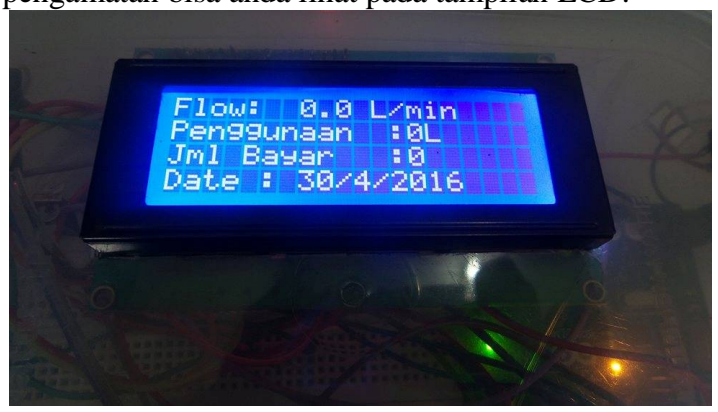

Gambar 12. Hasil Pengamatan Pengujian Arduino Uno

\section{b) Pengujian $L C D$}

Pengujian ini dilakukan untuk mengetahui hasil tampilan dari LCD 20" x 4". Pengujian dilakukan dengan menggunakan Arduino Uno sebagai alat untuk memerintahkan LCD menampilkan beberapa karakter. Pada pengujian LCD ini Arduino Uno diberi program untuk menampilkan karakter pada tiap baris. Pengujian berhasil jika LCD dapat menampilkan karakter sesuai yang ada di dalam program.

Tabel 4. Hasil Pengujian LCD

\begin{tabular}{|l|l|l|l|}
\hline Status & $\begin{array}{l}\text { Yang } \\
\text { diharapkan }\end{array}$ & Pengamatan & Kesimpulan \\
\hline Aktif & $\begin{array}{l}\text { Karakter sesuai } \\
\text { pada program }\end{array}$ & Pada LCD & Valid \\
\hline
\end{tabular}

Pada tabel pengujian LCD diatas dapat dijelaskan bahwa pada saat status aktif, yang diharapkan karakter sesuia pada program dengan melakukan pengamatan pada LCD dan kesimpulannya benar. 


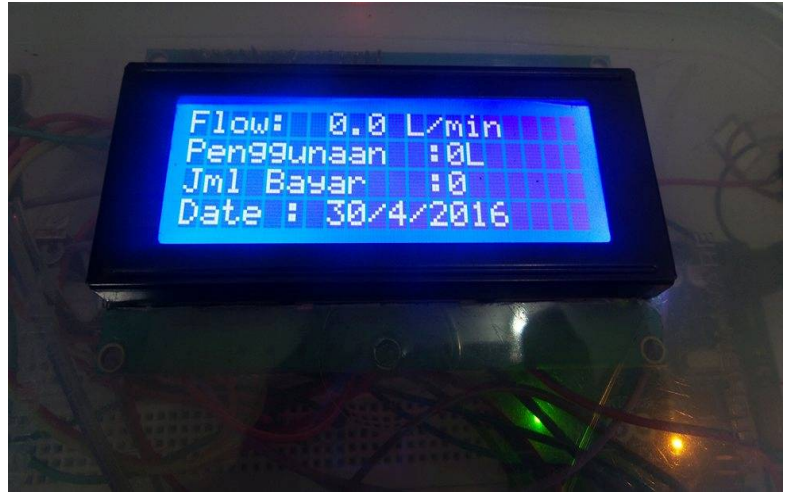

Gambar 13. Hasil Pengamatan Pengujian LCD

\section{3) Pengujian RTC}

Pengujian ini dilakukan untuk mengetahui tingkat keakuratan tanggal yang ada di dalam rangkaian RTC. Pengujian dilakukan dengan cara memberi program Arduino Uno untuk menampilkan jam, menit, detik dan juga hari, bulan dan tahun ke dalam serial monitor. Pengujian akan dianggap berhasil jika tanggal yang ditampilkan sesuai dengan tanggal pada kenyataan.

Tabel 5. Hasil Pengujian RTC

\begin{tabular}{|c|l|l|l|}
\hline Status & $\begin{array}{l}\text { Yang } \\
\text { diharapkan }\end{array}$ & Pengamatan & Kesimpulan \\
\hline Aktif & $\begin{array}{l}\text { Tanggal } \\
\text { yang } \\
\text { ditampilkan } \\
\text { sesuai } \\
\text { dengan } \\
\text { tanggal pada } \\
\text { program }\end{array}$ & Pada LCD & \\
\hline
\end{tabular}

Pada tabel pengujian pada RTC diatas dapat dijelaskan bahwa pada saat aktif tanggal yang ditampilkan sesuai dengan tanggal yang di input pada program dengan melakukan pengamatan pada LCD dan kesimpulan yang di dapat benar.

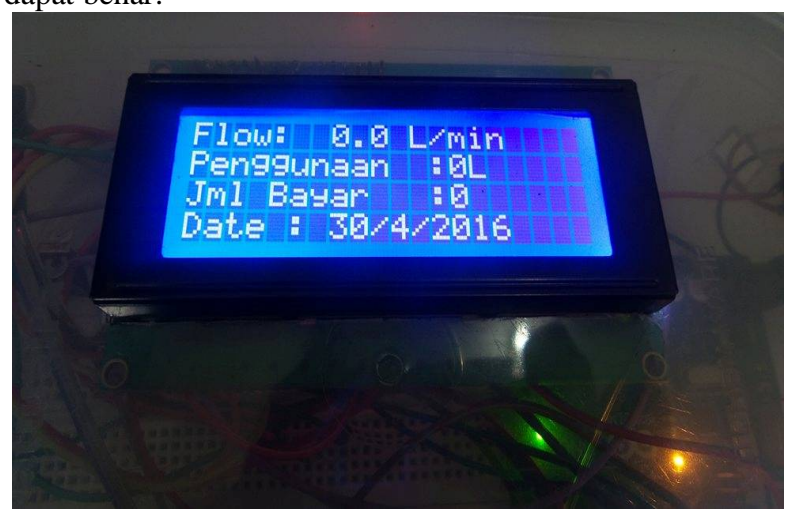

Gambar 14. Hasil Pengamatan Pengujian RTC

\section{4) Pengujian Water Flow Sensor}

Pengujian ini dilakukan untuk mengetahui kinerja sensor ketika dialiri air. Pengujian ini dilakukan dengan menggunakan hyper terminal pada arduino untuk monitoring perubahan putaran sensor ketika dialiri air. Pengujian ini berhasil jika sensor dapat berputar ketika dialiri air.

Tabel 6. Hasil Pengujian Water Flow Sensor

\begin{tabular}{|l|l|l|l|}
\hline Status & $\begin{array}{l}\text { Yang } \\
\text { diharapkan }\end{array}$ & Pengamatan & Kesimpulan \\
\hline Aktif & $\begin{array}{l}\text { Sensor } \\
\text { dapat } \\
\text { berputar } \\
\text { ketika } \\
\text { dialiri air }\end{array}$ & $\begin{array}{l}\text { Pada sensor } \\
\text { dan output } \\
\text { pada LCD }\end{array}$ & Valid \\
\hline
\end{tabular}

Pada tabel pengujian water flow sensor pada saat status aktif yang diharapkan sensor dapat berputar saat dialiri air dengan melakukan pengamatan pada sensor dan output pada LCD dan kesimpulan nya benar.

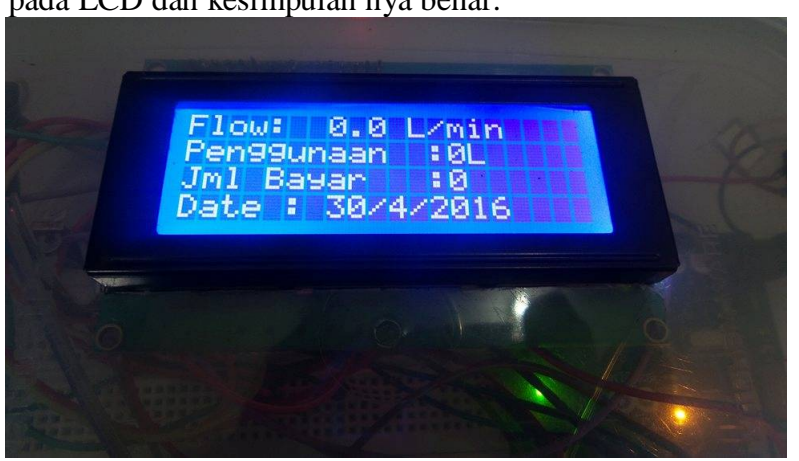

Gambar 15. Hasil Pengamatan Sensor

\section{5) Hasil Pengujian Keseluruhan}

Pengujian ini dilakukan untuk mengetahui kinerja keseluruhan sistem yang dibuat, pengujian dianggap berhasil jika seluruh sistem bekerja.

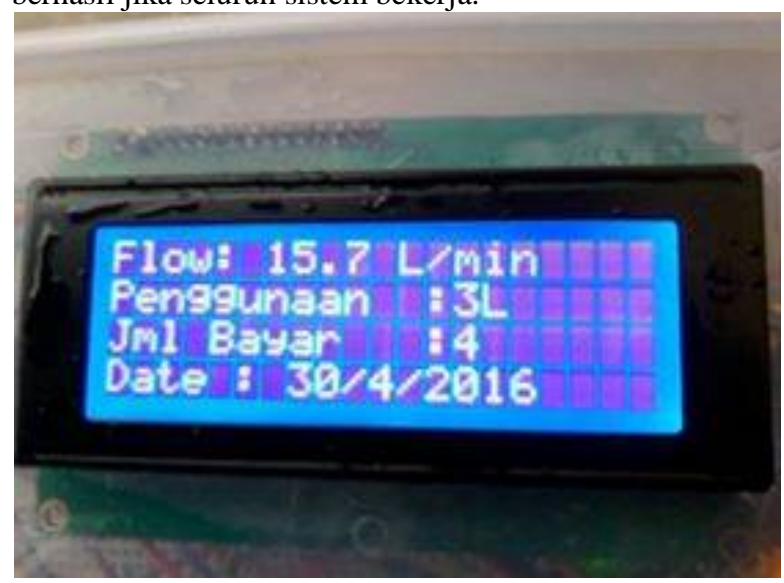

Gambar 16. Hasil Pengujian Keseluruhan 
Pada Gambar 16 hasil pengujian keseluruhan dapat dijelaskan dan di ambil sample pada flow 15,7 liter/menit pada penggunaan 3 liter dengan jumlah bayar 4 rupiah dan terhitung tanggal 30 bulan april 2016.

\section{PENUTUP}

\section{A. Kesimpulan}

Berdasarkan kesimpulan yang dapat diambil mengenai rancang bangun aplikasi monitoring penggunaan air PDAM berbasis mikrokontroler arduino unoyang telah penulis lakukan adalah sebagai berikut:

- Dengan adanya rancang bangun aplikasi monitoirng penggunaan air PDAM berbasis mikrokontroler arduino uno memudahkan masyarakat yang berlangganan air PDAM dalam menghitung debit air.

- Hasil dari perhitungan debit air ini dapat di lihat langsung pada LCD yang merupakan keluaran dari sistem tersebut.

- Penggunaan alat ini di peruntukkan untuk umum sehingga mereka bisa mengetahui atau menghitug langsung debit air yang mereka gunakan dan bukan di tujukan untuk perusahaan.

- Sampel yang di ambil mengidikasikan bahwa flow yang terjadi selama 15,7 liter/menit dengan penggunaan air sebanyak 3 liter dan jumlah yang harus di bayar sebanyak 4 rupiah dan terhitung tanggal 30 April 2016.

\section{B. Saran}

Penulis memberi beberapa saran yang dapat digunakan sebagai acuan dalam penelitian atau pengembangan selanjutnya, yaitu sebagai berikut :

- Agar perangkat ini dapat digunakan untuk melihat air tersebut layak di gunakan atau tidak, maka diperlukan sensor untuk mendeteksi kejernihan air.

- Untuk menyimpan data agar bisa di monitoring langsung oleh petugas PDAM ada baiknya tambahkan sistem.

- Untuk menyimpan data terdahulu ketika batere habis ada baik nya tambahkan database.

\section{DAFTAR PUSTAKA}

[1] Ashari Gumelar, dan Taofik Jasalesmana. Rancang Bangun Alat Ukur Suhu Air Pada Akuarium Air Tawar Berbasis Arduino Uno Terintegrasi WEB. Bogor: Pusat Penelitian Limnologi Lembaga Ilmu Pengetahuan Indonesia

[2] Evan Taruna Setiawan. 2015. Pengendali Lampu Rumah Berbasis Mikrokontroler Arduino Menggunakan Smartphone Android. Skripsi. STMIK Atma Luhur. Pangkalpinang

[3] Sumardi. 2013. Mikrokontroler Belajar AVR Mulai Dari Nol Yogyakarta: Graha Ilmu

[4] Syahwil, Muhammad. 2013. Panduan Mudah Simulasi Dan Praktek Mikrokontroler Arduino. Andi.

[5] Rizky, Soetam. 2011. Konsep Dasar Rekayasa Perangkat Lunak Jakarta: Prestasi Pustaka 